\title{
Protective Effects of Long Term Administration of Zinc on Bone Metabolism Parameters in Male Wistar Rats Treated with Cadmium
}

\author{
Shiva Najafi,, ${ }^{1,}$ Ali Asghar Moshtaghie, ${ }^{1}$ and Ali Noori ${ }^{2}$ \\ ${ }^{1}$ Department of Biochemistry, Faculty of Basic Sciences, Falavarjan Branch, Islamic Azad University, Isfahan, IR Iran \\ ${ }^{2}$ Department of Biology, Faculty of Basic Sciences, Falavarjan Branch, Islamic Azad University, Isfahan, IR Iran \\ "Corresponding author: Shiva Najafi, Department of Biochemistry, Faculty of Basic Sciences, Falavarjan Branch, Islamic Azad University, Isfahan, IR Iran. E-mail: \\ shivanajafi7@gmail.com
}

Received 2015 October 10; Revised 2015 December 26; Accepted 2016 October 28.

\begin{abstract}
Background: Violent poisoning by cadmium in human is created through drinks or meals which have packed in the metallic tins with cadmium plating. The symptoms of variation in the mineral metabolism of bones are observed and different conditions maybe appeared. The toxic (poisonous) effect due to cadmium can be neutralized by intervening zinc. This study has been designed to investigate the protective effects of zinc for reducing the poisonous effects due to cadmium on the metabolism in the parameters related to the bone in rat.

Methods: In this experimental study, 48 male rats of wistar species were distributed in eight experimental groups and tested in the investigative lab of Falavarjan university. These groups were received 0.5 cc physiological serum, $0.5 \mathrm{mg} / \mathrm{kg}$ Zinc, 0.5, 1, $2 \mathrm{mg} / \mathrm{kg}$ Cadmium respectively and some groups were included in those were taken all there cadmium and zinc concentrations synchronously. Blood samples were taken in a 60 days period and those factors related to the bone metabolism were measured. The data were analyzed by 2-ANOVA Ways, complementary tests through software SPSS 16.

Results: The results showed that $0.5,1,2 \mathrm{mg} / \mathrm{kg}$ doses cadmium chloride caused to increase alkaline Phosphatase, calcium, phosphorus, magnesium and decrease albumin as compared with control group. Also, synchronous usage of all three cadmium chloride concentrations with zinc cause to decrease alkaline phosphatase, calcium, phosphorus, magnesium and increase albumin concentration. In a word, the other bone parameters have been significant in different cadmium and zinc doses $(\mathrm{P}<0.05)$.

Conclusions: Findings showed that zinc can play a protective role on the metabolism parameters related to bone against to poisoning caused by cadmium.
\end{abstract}

Keywords: Cadmium, Bone, Zinc

\section{Background}

Cadmium is an industrial pollutant which may cause violent and chronic poisoning in human and animals. Cadmium can interfere in metabolic path of many elements including copper, zinc, calcium etc. causing disorder in the biologic activities [1, 2]. Also, it may disrupt the balance of electrolytes in plasma [3]. The rate of cadmium absorption by humans digestive system is $4.7 \%-7 \%$, and it is $0.5 \%-12 \%$ in laboratory animals. According to the experiments, calcium, protein, and vitamin B6 (pyridoxine) deficiency in regimen may increase cadmium absorption and enhance it to quadruple more than the normal level [4]. The researches have showed that cadmium may cause variation in alkaline phosphatase, calcium, phosphorus, magnesium and albumin [5-7]. On one hand, the influence of nourishing factors and some rare elements have been reported for metabolism process of the bone tissue in human and different animals [8, 9]. Among the macro ele- ments, calcium and phosphorus play important role for the bone tissue in animals. As, it was mentioned, many skeleton abnormalities have been occurred by cadmium injection in different doses to rats. Although, cadmium is toxic for bone, the main mechanisms for developing osteoporosis and osteomalacia in humans with chronic pollution of cadmium has not been recognized completely. Arno (2010) by a general assessment in Sweden has studied bone indices that by increasing the rate of cadmium in body, bone decomposition will be increased [10]. Zinc is a scarce and necessary for skeleton growth, various enzymes structures and their performance. The biologic importance of zinc is related to its contribution to metalluenzymes structures [11]. The activity of different enzymes such as pancreatic carboxy peptidase A, thymidine kinase and alkaline phosphatase may be decreased due to zinc deficiency, where as the activity of some dehydrogenase are not as same as them. The recent investigations have 
pointed to its vital role in most body systems. In the past decade, it is proved that zinc has important role for intra cellular signaling and ionic signal [12]. Many experiments have shown that zinc prevents to reduce bone growth due to cadmium and it has a protective role. The studies have shown that zinc increase on cellular cultivation condition cause to increase their growth and it can stop the cadmium destructive effect [13]. In addition, a study on 60 patients with bone fracture showed that consuming zinc complementary for 60 days may cause significant increase of zinc in serum. The relation between the zinc in diet and its serum is harmonious. Also, plasma zinc is related to the final intake of zinc and the complementary of zinc consumption is related to the nutritional intake [14]. In this study, according to the available resources. The rate of influencing cadmium and zinc protective effect in metabolism process related to the bone tissue on male rat of wistar species are discussed.

\section{Methods}

In this experimental study, cadmium chloride $\left(\mathrm{H}_{2} \mathrm{O}_{1 / 2} \mathrm{CdCl}_{.2}\right)$ from companies products and zinc chloride $\left(\mathrm{ZnCl}_{.2}\right)$ (New Jersey, USA) were used.

The male rat of wistar species with the average weight $200 \pm 50$ was used which was provided from animals' nest of Falavarjan University. The rats were divided into 8 groups, 6 rats in each group. The control group received 0.5 cc physiology serum daily by intra peritoneum. The rats were kept in $37^{\circ} \mathrm{C}$ at room temperature and they were weighted once a week before injection, and the concentration rate of solutions was variable according to the new weights of the rats. All of these experiments weights of the rats. All of these experiments were done in Falavarjan university laboratory. Other three groups were injected $0.5,1$ and $2 \mathrm{mg} / \mathrm{kg}$ cadmium chloride. Another group received $0.5 \mathrm{mg}$ zinc per kilogram and the other three groups were injected the cadmium doses in $0.5,1$ and 2 concentrations with $0.5 \mathrm{mg} / \mathrm{kg}$ zinc. The injections were daily intraperitoneum. The suspensions (solutions) were kept in bottles and prepared daily. The solvent for solution and massiveness was serum physiology $0.9 \%$. At the end of injections, the rats were anaesthetized by injecting a composition.

Consists of ketamin $0.07 \%$ and zilazin $0.05 \%$ and then blood sampling was done from heart. Those blood samples were poured in acid-washed vitreous prepared for tests. The serum was separated from blood cells by centrifuge in 2000 - 3000 momentum in each minute. The degree of related parameters with bone metabolic consists of alkaline phosphatase, calcium, phosphorus, magnesium and albumin were measured by experimental current methods and the other ways. DGKC method (Germany Biochemistry Association standard) was used for measuring alkaline phosphatase. Also, photometric method by creolphthalein complex one for measuring calcium and photometric UV test for measuring phosphorus degree were used. Xylidyl Blue was used to measure magnesium and calorimetric (BCG) was used to measure albumin rate. The measuring methods for alkaline phosphatase, calcium, phosphorus and magnesium were product of pars Azmoon Co (Tehran, Iran), and the measuring method for albumin was product of Greener Co (Germany). Biochemistry experiments was done by Auto-Analyzer machinery, Hitachi 717. The data were analyzed by 2-ANOVA Ways, complementary tests through software SPSS 16. P value was statistically significant $(\mathrm{P}<0.05)$.

\section{Results}

After analyses, the rate of variations were analysed in the concentrations related to the parameters compared to control group and the groups linked to zinc chloride (Table 1). As the Figure 1 shows, the doses $1,2 \mathrm{mg}$ per unit $1 \mathrm{~kg}$ body weight, cadmium causes to increase alkaline phosphatase in rats blood in comparison with control group. Figure 2 related to calcium shows different doses of cadmium may increase this degree compared to control group. In Figure 3, all three cadmium concentrations have increased in comparison with control group. In Figure 4, magnesium element has increased due to injecting cadmium in 35, 38 and $40 \%$ in compared to control group. But, regarding to Figure 5, the rate of albumin has decreased to 3.97, 9.25\% and $19.81 \%$ in comparison to control group $(\mathrm{P}<0.05)$. In following injecting the zinc chloride to different groups, in comparison to control group, has caused to $19 \%$ decrease in alkaline phosphatase, Also, it has increased calcium rate to $14 \%$. Phosphorus has increased to $5 \%$. It has increased magnesium to $53 \%$. But it has reduced albumin to $2.32 \%$. $(\mathrm{P}<0.05)$. The influence of zinc protective effects on cadmium poisoning on the bone metabolism and jointly. Effects of zinc and cadmium on the mentioned parameters were studied. The results show that zinc in linked, doses has decreased alkaline phosphatase to $28.94 \%$ and $42.84 \%$, in compared with the cadmium groups (Figure 1). Also, after injecting cadmium, calcium has increased to $17 \%$ and $18 \%$ against to the control group (Figure 2), and after injecting zinc it has decreased to $8.66 \%$ and $5.22 \%$ against two groups only with cadmium (Figure 3 ). We observed the magnesium has increased to $38 \%$ and $40 \%$ due to injecting cadmium, against to control group, but after injecting zinc chloride to the linked groups, it has decreased to $8.41 \%$ and $8.07 \%$ against to the cadmium group (Figure 4 ). By injecting cadmium, albumin has decreased to $9.25 \%$ and 
$19.81 \%$ against to the control group, but by injecting zinc to the linked (joint) groups, it has enhanced to $0.02 \%$ and $11 \%$ against to the cadmium groups (Figure 5$)(\mathrm{P}<0.05)$.

Figure 1. It Shows the Rate of Alkaline Enzyme Function of Blood Serum Phosphatase in Rats During a Trial Period 60 Days

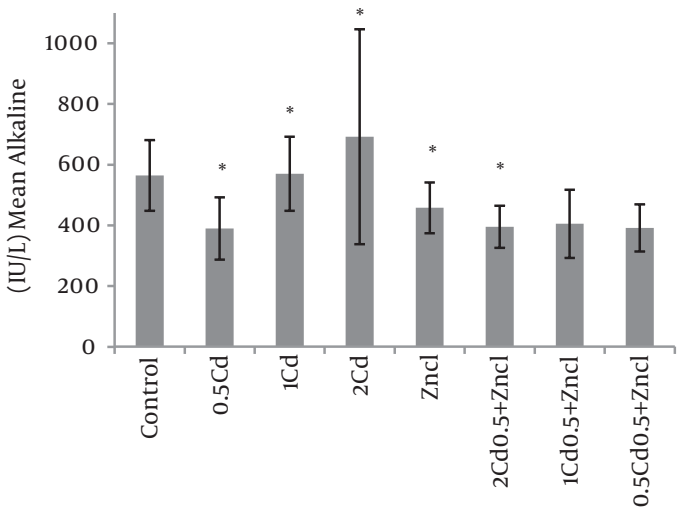

The injected concentration $(\mathrm{mg} / \mathrm{kg})$ body weight

The significant differences are presented by $\left({ }^{*}\right)(\mathrm{P}<0.05)$. The control group received serum physiology (mean $\pm \mathrm{SD}$ ).

Figure 2. It Shows Serum Calcium Concentration in the Rats During 60 Days Period

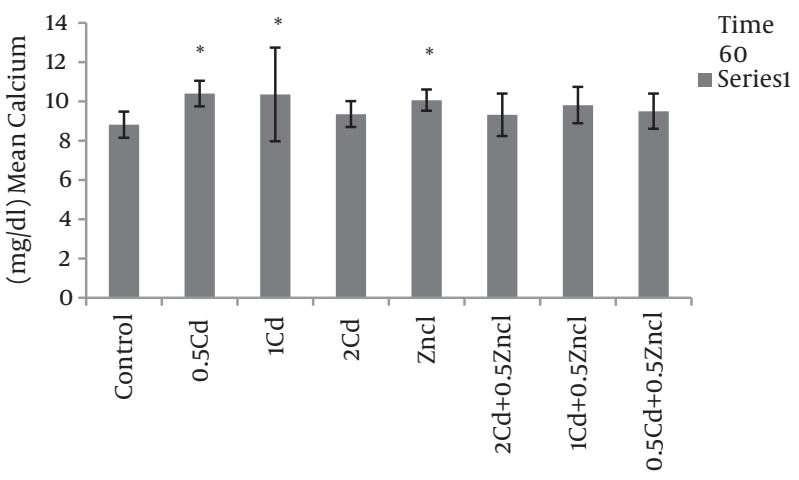

The injected concentration $(\mathrm{mg} / \mathrm{kg})$ body weight

The significant differences are shown by $\left({ }^{*}\right)(\mathrm{P}<0.05)$. The control group received serum physiology (mean $\pm \mathrm{SD}$ ).

\section{Discussion}

It is clear that cadmium cause the great disorders in the body functions $[1,2,15]$. The data derived from our previous studies shows that this factor (cadmium) has influenced on laboratory rats livers and kidneys. It may cause serious damages for ferrous metabolism [1]. The data due to this study shows that the bone disorders may occur in the rats
Figure 3. Phosphorus Concentration in the Rats Blood Serum is Shown During a Test Period 60 Days

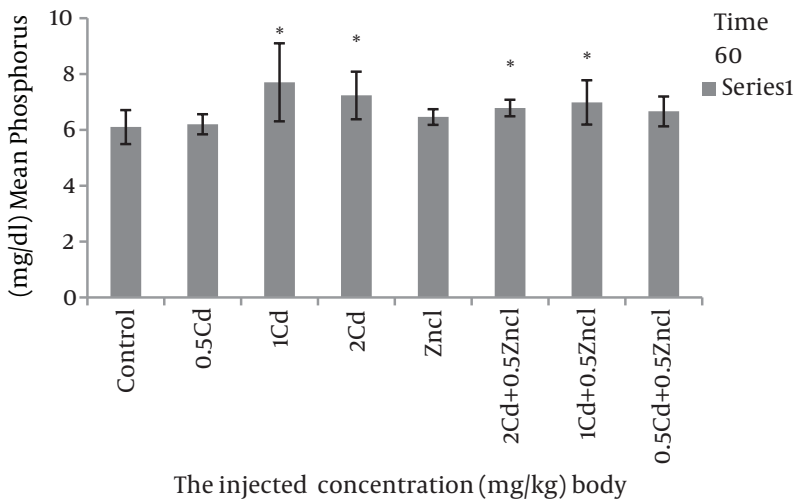

The significant differences is shown by $\left(^{*}\right)(\mathrm{P}<0.05)$. The control group received serum physiology (mean $\pm S D$ ).

Figure 4. The Magnesium Concentration in the Rats Blood Serum is Shown During a 60 Days Period

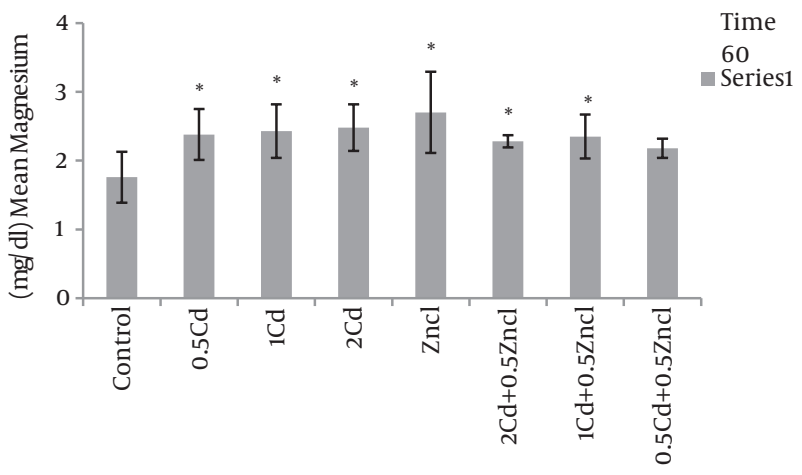

The injected concentration $(\mathrm{mg} / \mathrm{kg})$ body weight

Significant differences are shown by $\left({ }^{*}\right)(\mathrm{P}<0.05)$. The control group received serum physiology (mean $\pm \mathrm{SD}$ ).

subjected to the different doses of cadmium. The recent studies have shown that little cadmium pollution such as smoking may resulted in Osteoporosis [16]. Cadmium is found in environment as a toxic element. When the humans and animals are exposed to this metal, their skeletons will be damaged. Also, low bone mass and osteoporosis and fracture have been reported in animals [10]. Cadmium can place in the metabolic procedures of many elements including zinc, copper, calcium and etc, and cause disorder in their biologic function. The skeleton disorders and bone deformities are mostly because of environmental cadmium [17]. According to the investigations in recent years, it is observed that different doses of cadmium, after measuring the concentration of alkaline phosphatase 
Table 1. The Cadmium Effects on the Parameters Related to the Bone Metabolism and Zinc Protective Effect on it During 60 Days

\begin{tabular}{|c|c|c|c|c|c|}
\hline Treatment Group, Mg/kg & ALP, IU/L & $\mathrm{Ca}, \mathrm{mg} / \mathrm{dL}$ & $\mathbf{P}, \mathbf{m g} / \mathbf{d L}$ & $M g, m g / d L$ & Alb, mg/dI \\
\hline Control & $564.50 \pm 116.13$ & $8.81 \pm 0.67$ & $6.1 \pm 0.61$ & $1.76 \pm 0.37$ & $3.03 \pm 0.08$ \\
\hline $0.5 \mathrm{Cd}$ & $390 \pm 102.76^{\mathrm{a}}$ & $10.40 \pm 0.65^{\mathrm{a}}$ & $6.2 \pm 0.36$ & $2.38 \pm 0.37^{\mathrm{a}}$ & $2.91 \pm 0.07$ \\
\hline 1Cd & $570.16 \pm 121.8^{\mathrm{a}}$ & $10.35 \pm 2.38^{\mathrm{a}}$ & $7.70 \pm 1.40^{\mathrm{a}}$ & $2.43 \pm 0.39^{\mathrm{a}}$ & $2.75 \pm 0.23$ \\
\hline 2Cd & $692.16 \pm 354.11^{\mathrm{a}}$ & $9.35 \pm 0.66$ & $7.23 \pm 0.85^{\mathrm{a}}$ & $2.48 \pm 0.34^{\mathrm{a}}$ & $2.43 \pm 0.32^{\mathrm{a}}$ \\
\hline Zncl & $458 \pm 83.80^{\mathrm{a}}$ & $10.06 \pm 0.54^{\mathrm{a}}$ & $6.46 \pm 0.28$ & $2.70 \pm 0.59^{\mathrm{a}}$ & $2.96 \pm 0.16$ \\
\hline $2 \mathrm{~cd}+0.5 \mathrm{zncl}$ & $395.66 \pm 69.47^{\mathrm{a}}$ & $9.31 \pm 1.08$ & $6.78 \pm 0.30^{\mathrm{a}}$ & $2.28 \pm 0.09^{\mathrm{a}}$ & $2.71 \pm 0.14$ \\
\hline $1 \mathrm{~cd}+0.5 \mathrm{zncl}$ & $405.16 \pm 112.46$ & $9.81 \pm 0.93$ & $6.98 \pm 0.79^{a}$ & $2.35 \pm 0.32^{\mathrm{a}}$ & $2.81 \pm 0.26$ \\
\hline $0.5 \mathrm{~cd}+0.5 \mathrm{zncl}$ & $391.66 \pm 77.41$ & $9.50 \pm 0.90$ & $6.66 \pm 0.53$ & $2.18 \pm 0.14$ & $2.98 \pm 0.14$ \\
\hline
\end{tabular}

${ }^{\mathrm{a}}$ There was a significant differences $(\mathrm{P}<0.05)$ between the $\mathrm{Zncl}, 2 \mathrm{Cd}, 1 \mathrm{Cd}, 0.5 \mathrm{Cd}$ groups compared with control group and comparison combined groups with exclusive cadmium group.

Figure 5. The Serum Albumin Concentration is Shown During a 60 Days Period

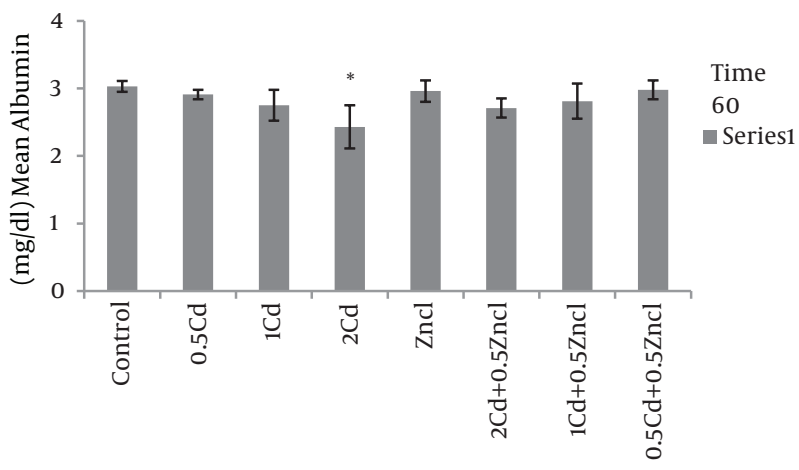

The injected concentration $(\mathrm{mg} / \mathrm{kg})$ body weight

The significant differences are presented by $\left({ }^{*}\right)(\mathrm{P}<0.05)$. The control group received serum physiology (mean \pm SD).

enzyme, cause to increase the rate of this enzyme compared to the control group [18]. In other study in 2007, on rats biochemical factors and, the rate of alkaline phosphatase enzyme activity has increased in comparison with control group. These results were in accordance with longterm doses 1, $2 \mathrm{mg} / \mathrm{kg}$ cadmium that enhance the alkaline phosphatase activity [19]. Enhancing the function of alkaline phosphatase in high doses cadmium maybe due to cadmium which impairs the bone tissue and this enzyme exists in osteoblustoma cells and it is necessary for bonemaking and has increased in blood circulation [20]. But, injecting zinc and cadmium jointly has resulted in decrease the enzyme function that it may be due to the zinc protective effect on cadmium and prevents to impair bones by cadmium and leaving this enzyme by bones. The effects of concentration 0.5 on alkaline phosphatase function indicate to decrease the enzyme synthesis and pre- vents producing this enzyme in the cells. As while as high concentration shows impairing liver cells and leaving enzyme into cytoplasm which means high concentration of enzyme. The researches show that calcification process will be disordered when the rate of alkaline phosphatase decreased. This process is happened in hypophosphates illness. Calcium and phosphorus sediment is not only as a simple passive physicochemical process and it seems that pyrophosphate is as a controller for calcification phase. So, it is necessary to remove it in environment and the alkaline phosphatase enzyme which catalyze the breakdown of mineral pyrophosphate, has an important role in this case [21]. In a study (2007) on the rats biochemical factors which were exposed to different doses of cadmium, showed that in comparison with the control group, the rate of calcium has increased. This study is in conformity with the long term results of the present project [19]. Enhancing calcium plasma concentration or hypocalcaemia is occurred mostlyin skeleton disease such as bone carcinoma, osteoporosis, and,etc. Such increase in long-term may be in the reason of physiologic conditions and unbalancing among three parts of calcium and albumin plasma concentration and hydrogen Ionia. Also, the zinc has induced its protective effect by decreasing calcium in different groups [14]. As, the major consumption of calcium in the cell is used to transfer ming calmodulin. It is possible that zinc in this concentration prevents calmodulin synthesis, and finally, cause to release calcium out of cell. In relation to phosphorus, in a study (1390) it is observed that different doses of cadmium cause significant increase in phosphorus in carp's serum against to control group [18]. It is conformed to the results in this study. Enhancing phosphorus in the long term group shows, since the phosphorus has changed into complex $3 \mathrm{Ca}_{3}\left(\mathrm{PO}_{4}\right)_{2}$ with calcium, the effect due to cadmium may cause to destroy the skeletal 
tissue and indicates releasing calcium and phosphorus in circulation [22]. Influencing the zinc as well as its decrease on calcium concentration indicates the decrease in phosphorus and reducing the damage to the skeleton tissue [23]. Increasing the rate of calcium, may present that cadmium has influenced on the bone metabolism and by destroying it, has caused to releasing magnesium ion from the skeleton tissue that finally results in increasing magnesium plasma concentration. It seems there is a competition between zinc and magnesium which caused to decrease magnesium in blood [24-26]. The results shows that zinc can neutralize the poisonous effect of cadmium, because magnesium has interfered in the most enzymes reactions such as kinases and phosphatases, and cadmium by its toxic effect on the synthesis may prevent the synthesis and releasing magnesium in the circulation, and zinc may neutralize the cadmium poisonous effects by its biologic effect and competing with cadmium. Most of the renal diseases are the consequences of increasing magnesium plasma concentration, but in this experiment, the magnesium plays the role of a factor and its concentration may increase when the concentration of calcium plasma is high, whereas, in the presence of zinc, magnesium reduction is subject to the many factors that it results in disorder in sodium and potassium metabolism some times. Many people experience the decrease in the concentration of potassium plasma may suffer from calcium deficiency which is related to the decrease in magnesium. Zinc and magnesium perform as two agonist elements in connecting to the plasma proteins and thus, magnesium juncture to albumin serum has occurred in the presence of zinc and it has caused the increase of magnesium plasma. But, in this study, decreasing magnesium in the groups which have been injected zinc, is the result of its protective effect on the magnesium rate [27-29]. According to the investigations, most albumin out of vessel is replaceable with plasma albumin. As while as for bone, it is interchangeable only in the tissue fluid. The remained parts are in the calcification matrix and it has proven permanently. Twentyseven percent albumin in the young bone is in the tissue fluid and there is about $57 \%$ in the calcification matrix, and about $16 \%$ is intra-vessel. The whole volume albumin out of vessel in per unit of bone mass is similar to which is in the soft tissue $[28,30,31]$. The mechanism for decreasing albumin concentration is because of destroying the liver cells following receiving cadmium that this reduction has been neutralized by injecting zinc and then the albumin has returned to its preliminary concentration that indicates zinc has had the preventive effect on cadmium effect. On the one hand, zinc with its competitive effect against cadmium, may prevent entering this toxic element to the liver and so, the albumin synthesis has changed into the normal condition which is may related to its effect on the intermediary enzymes for synthesizing this protein. Albumin is as a calcium carrier in circulation and also as a balance source for calcium ion. Therefore, in the cases that albumin concentration is reduced, the metabolism in the bone maybe disordered. In this reason, it is necessary that measuring the calcium ion in the children and measuring the albumin rate are done synchronously. As decreasing albumin results in the bone diseases. Since, albumin is an important carrier for calcium, reducing its concentration may cause calcium reduction related to protein (Figure 5), and it has caused increasing the ionized calcium. And thus, the results of this study can indicate that increasing free calcium in plasma is in the following of injecting cadmium [32-34].

In Conclusion, it is resulted that cadmium has toxic effect and may cause variation in the metabolism of related parameters to the bone metabolism, especially, this effect is obvious in high doses, but the toxic effect may be reduced by zinc injection. It is possible that zinc influence on the bone in two ways. Firstly, it may prevent entering cadmium to the bone or skeletal tissue and plays a protective role for the bone, and furthermore, zinc is one of necessary and rare components and has a role for bones growth and increasing the factors which are effective on the bone growth, including the enzymes $[18,31]$. According to these study findings and the reports from other investigation, it is concluded that cadmium in vivo causes poisonous and disorders in the body, and zinc can have a protective effect against such toxic.

\section{Acknowledgments}

It is eligible to give my thanks to the personnel in the laboratory of Azad University Branch of Falavarjan and also, Esfahan Al.Zahra hospital. I thank Dr. Moayednia regarding to his contributions for this study. Project code is 17230520921003 , that is done by Shiva Najafi.

\section{Footnotes}

Authors' Contribution: All authors had equal role in design, work, statistical analysis, and manuscript writing.

Conflict of Interest: The authors declare no conflict of interest.

Funding/Support: Faculty of Basic Science, Falavarjan Branch, Isfahan. 


\section{References}

1. Moshtaghie AA, Taghikhani M, Sandughchin M. Cadmium interaction with iron metabolism. In vitro and in vivo studies. Clin Chem Enzymol Commun. 1997;7(5):307-16.

2. Jezierska B, Witeska M. Metal toxicity to fish. Poland: University of Podlasie; 2001.

3. Witeska M, Jezierska B, Wolnicki J. Respiratory and hematological response of tench, Tinca tinca (L.) to a short-term cadmium exposure. Aquaculture Int. 2006;14(1-2):141-52.

4. McGeer JC, Niyogi S, Smith DS. Homeostasis and toxicology of nonessential metals Available from: http://agris.fao.org/agris-search/ search.do?recordID=US201300002642.

5. Velmurugan B, Selvanayagam M, Cengiz EI, Uysal E. Levels of transaminases, alkaline phosphatase, and protein in tissues of Clarias gariepienus fingerlings exposed to sublethal concentrations of cadmium chloride. Environ Toxicol. 2008;23(6):672-8. doi: 10.1002/tox.20372. [PubMed: 18247418].

6. Al-Attar AM. Biochemical effects of short-term cadmium exposure on the freshwater fish, Oreochromis niloticus. J Biol Sci. 2005;5(3):260-5.

7. Gill TS, Tewari H, Pande J. In vivo and in vitro effects of cadmium on selected enzymes in different organs of the fish Barbus conchonius Ham.(rosy barb). Comp Biochem Physiol C. 1991;100(3):501-5. [PubMed: 1687547].

8. Lall SP, Lewis-McCrea LM. Role of nutrients in skeletal metabolism and pathology in fish-an overview. Aquaculture. 2007;267(1):3-19.

9. Beattie JH, Avenell A. Trace element nutrition and bone metabolism. Nutr Res Rev. 1992;5(1):167-88. doi: 10.1079/NRR19920013. [PubMed: 19094319].

10. Arno H. Bone Metabolism 2010. Available from: http://www. helmberg.at/bone-metabolism.htm.

11. Matovic V, Buha A, Bulat Z, Dukic-Cosic D. Cadmium toxicity revisited: focus on oxidative stress induction and interactions with zinc and magnesium. Arh Hig Rada Toksikol. 2011;62(1):65-76. doi: 10.2478/10004-1254-62-2011-2075. [PubMed: 21421535].

12. Rajendra R, Balakumar C, Ahammed HAM, Jayakumar S, Vaideki K, Rajesh E. Use of zinc oxide nano particles for production of antimicrobial textiles. Int J Engin Sci Technol. 2010;2(1):202-8.

13. Hill T, Meunier N, Andriollo-Sanchez M, Ciarapica D, Hininger-Favier I, Polito A, et al. The relationship between the zinc nutritive status and biochemical markers of bone turnover in older European adults: the ZENITH study. Eur J Clin Nutr. 2005;59 Suppl 2:S73-8. doi: 10.1038/sj.ejcn.1602303. [PubMed: 16254587].

14. Igarashi A, Yamaguchi M. Great increase in bone $66 \mathrm{kDa}$ protein and osteocalcin at later stages with healing rat fractures: effect of zinc treatment. Int J Mol Med. 2003;11(2):223-8. [PubMed: 12525882].

15. Szczerbik P, Mikolajczyk T, Sokolowska-Mikolajczyk M, Socha M, Chyb J, Epler P. Influence of long-term exposure to dietary cadmium on growth, maturation and reproduction of goldfish (subspecies: Prussian carp Carassius auratus gibelio B.). Aquat Toxicol. 2006;77(2):12635. doi: 10.1016/j.aquatox.2005.11.005. [PubMed: 16406109].

16. Akesson A, Bjellerup P, Lundh T, Lidfeldt J, Nerbrand C, Samsioe $\mathrm{G}$, et al. Cadmium-induced effects on bone in a population-based study of women. Environ Health Perspect. 2006;114(6):830-4. [PubMed: 16759980].

17. Noel L, Guerin T, Kolf-Clauw M. Subchronic dietary exposure of rats to cadmium alters the metabolism of metals essential to bone health. Food Chem Toxicol. 2004;42(8):1203-10. doi: 10.1016/j.fct.2004.02.017. [PubMed: 15207369].

18. Malekpouri P, Moshtaghie AA, Kazemian M, Soltani M. Protective effect of zinc on related parameters to bone metabolism in common carp fish (Cyprinus carpio L.) intoxified with cadmium. Fish Physiol Biochem. 2011;37(1):187-96. doi: 10.1007/s10695-010-9430-7. [PubMed: 20839051].

19. Comelekoglu U, Yalin S, Bagis S, Ogenler O, Sahin NO, Yildiz A et al. Low-exposure cadmium is more toxic on osteoporotic rat femoral bone: mechanical, biochemical, and histopathological evaluation. Ecotoxicol Environ Saf. 2007;66(2):267-71. doi: 10.1016/j.ecoenv.2006.01.006. [PubMed:16530835].

20. Skillen AW, Harrison J. Serum alkaline phosphatases. Effect of $\mathrm{pH}$ and buffer on optimum substrate concentration. Clin Chim Acta. 1973;45(3):287-91. [PubMed: 4708058].

21. Sadighi A, Roshan MM, Moradi A, Ostadrahimi A. The effects of zinc supplementation on serum zinc, alkaline phosphatase activity and fracture healing of bones. Saudi Med J. 2008;29(9):1276-9. [PubMed: 18813411].

22. Hyun TH, Barrett-Connor E, Milne DB. Zinc intakes and plasma concentrations in men with osteoporosis: the Rancho Bernardo Study. Am J Clin Nutr. 2004;80(3):715-21. [PubMed: 15321813].

23. Brzoska MM, Moniuszko-Jakoniuk J. Low-level lifetime exposure to cadmium decreases skeletal mineralization and enhances bone loss in aged rats. Bone. 2004;35(5):1180-91. doi:10.1016/j.bone.2004.07.010. [PubMed: 15542044]

24. Jimenez-Ortega V, Cano-Barquilla P, Scacchi PA, Cardinali DP, Esquifino AI. Cadmium-Induced Disruption in 24-h Expression of Clock and Redox Enzyme Genes in Rat Medial Basal Hypothalamus: Prevention by Melatonin. Front Neurol. 2011;2:13. doi: 10.3389/fneur.2011.00013. [PubMed: 21442002].

25. Lonnerdal B. Dietary factors influencing zinc absorption. J Nutr. 2000;130(5S Suppl):1378S-83S. [PubMed: 10801947].

26. Bulat Z, Dukic-Cosic D, Antonijevic B, Bulat P, Vujanovic D, Buha A, et al. Effect of magnesium supplementation on the distribution patterns of zinc, copper, and magnesium in rabbits exposed to prolonged cadmium intoxication. ScientificWorldjournal. 2012;2012:572514. doi: 10.1100/2012/572514. [PubMed: 22701362].

27. Calhoun NR, Smith JJ, Becker KL. The role of zinc in bone metabolism Clin Orthop Relat Res. 1974(103):212-34. [PubMed: 4213480].

28. Relea P, Revilla M, Ripoll E, Arribas I, Villa LF, Rico H. Zinc, biochemical markers of nutrition, and type I osteoporosis. Age Ageing. 1995;24(4):303-7. [PubMed: 7484487].

29. Clark PJ, Eastell R, Barker ME. Zinc supplementation and bone growth in pubertal girls. Lancet. 1999;354(9177):485. doi: 10.1016/S01406736(99)01290-8. [PubMed: 10465179].

30. Brzoska MM, Moniuszko-Jakoniuk J. Low-level exposure to cadmium during the lifetime increases the risk of osteoporosis and fractures of the lumbar spine in the elderly: studies on a rat model of human environmental exposure. Toxicol Sci. 2004;82(2):468-77. doi: 10.1093/toxsci/kfh275. [PubMed: 15375291].

31. Obianime AW, Roberts I. Antioxidants, cadmium-induced toxicity, serum biochemical and the histological abnormalities of the kidney and testes of the male Wistar rats. Niger JPhysiol Sci. 2009;24(2):177-85. [PubMed: 20234761].

32. Miyahara T, Takata M, Mori-Uchi S, Miyata M, Nagai M, Sugure A, et al Stimulative effects of cadmium on bone resorption in neonatal parietal bone resorption. Toxicology. 1992;73(1):93-9. [PubMed: 1589882].

33. Zhang YH, Cheng YY, Hong Y, Wang DL, Li ST. [Effects of zinc deficiency on bone mineralization and its mechanism in rats]. Zhonghua Yu Fang Yi Xue Za Zhi. 2003;37(2):121-4. [PubMed:12839666].

34. Roopha PD, Michael JS, Padmalatha C, Singh AJAR. Cadmium toxicity exposure Induced oxidative stress in postnatal development of Wistar rats. J Toxicol Environ Health Sci. 2011;3(7):176-9. 